\title{
Sámi reindeer governance in Norway as competing knowledge systems: a participatory study
}

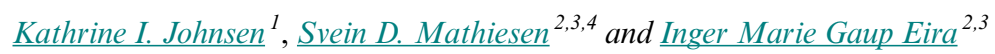

\begin{abstract}
Using a participatory research approach, we assess the knowledge systems and political ontology of reindeer husbandry. The study was conducted by a mixed team of scientists and Sámi reindeer herders who practiced reindeer husbandry in West Finnmark, northern Norway, both prior to and during the state-led "rationalization" of Sámi reindeer husbandry since the late 1970s. The analysis is based on the participants' reindeer herding knowledge and their assessment of the governance of Sámi pastoralism. Two future narratives (scenarios) were used to stimulate reflection and discussion. Based on these discussions and by studying secondary sources, we examined how herders and government officials explained what reindeer husbandry is and ought to be and their conceptions about "proper" management of reindeer, herders, and the land on which reindeer pastoralism depends. We find that the state governance of reindeer husbandry since the end of the 1970s promoted, through a combination of economic incentives and sanctions, herding practices primarily based on Western knowledge and way of understanding the world. This knowledge system and the management techniques it promotes was, and still is, in conflict with and undermines reindeer herding knowledge and worldviews. However, despite 40 years of policies attempting to transform reindeer husbandry according to the state's perception of proper pastoralism, a Sámi worldview continues to influence the herders' understanding of the relationship between humans, reindeer, and nature and how this relationship should be governed. Nonetheless, the conflicting, asymmetrical knowledge systems and competing worldviews of what reindeer husbandry is and ought to be compromise the identity and rights of the pastoralists.
\end{abstract}

Key Words: knowledge; participatory research; political ontology; reindeer husbandry; Sámi; scenarios

\section{INTRODUCTION}

After the Second World War, a development discourse evolved in the Western world, which was based on the Western policy makers' notions of modernity, rationality, material progress, the potential of science, and the value of equality and social justice (Peet and Hartwick 2009). In this discourse, rationalism was the capacity for humans to control the world through thought, logic, and calculation. Through rationality, often measured in economic imperatives, the world could be changed to the better (Tucker 1999, Peet and Hartwick 2009). When exploring notions of development, however, Tucker (1999:3) suggests distinguishing between two types of processes of change: one that "concerns the production of goods, the mastery over nature, rational organization and technological efficiency," and a second that "concerns the production of structures of power and ideology." To recognize the two types of change embedded in the mainstream Western concept of development, Tucker (1999) suggested deconstructing it and assessing its knowledge base and worldview, as well as how it supports economic and political structures of domination.

Social anthropologist Robert Paine, who studied Sámi reindeer husbandry in northern Norway from the 1960s to the 1990s, distinguished between the "rationalization" and "modernization" of reindeer husbandry (Paine 1994). He explained modernization as changes that come of their own accord (e.g., motorized vehicles and electricity) and rationalization as an induced change "informed by an economic ideology of equality combined with market efficiency" (Paine 1994:142). Using Paine's distinction between rationalization and modernization, and with a focus on Sámi reindeer husbandry in West Finnmark, northern Norway, we address two key questions: (1) How do herders and government officials explain what reindeer husbandry is and ought to be? (2) What are the actors' presentations about "rational" management of reindeer, herders, and the land on which reindeer pastoralism depends?

In line with Bridge and Perreault (2009) and Johnsen et al. (2015), we understand the governance of reindeer husbandry as both the social organization of decision making related to reindeer and the production of social order through the administration of reindeer herding and husbandry. Through a participatory approach, we examine the Norwegian state governance since $1966^{[1]}$ and the traditional Sámi governance of reindeer husbandry in West Finnmark. Whereas traditional knowledge had a dominant role in practical reindeer husbandry prior to the 1970s, the state governance regime has since promoted herding practices primarily informed by a Western scientific perspective on meat production. We show that the state and the reindeer herders had, and still have, conflicting understandings of what Sámi reindeer husbandry is and ought to be. Furthermore, we find that the political reform of the late 1970s undermined the herders' knowledge and worldviews related to sustainable Sámi reindeer husbandry and challenge their identity and rights.

This article contributes to the academic discussion on political ontology, introduced by Blaser (2009a). Political ontology concerns power relations and conflicts that arise when different

${ }^{1}$ Department of International Environment and Development Studies (Noragric), Norwegian University of Life Sciences, Norway, ${ }^{2}$ Sámi University of Applied Sciences, Kautokeino, Norway, ${ }^{3}$ UArctic EALAT Institute at International Centre for Reindeer Husbandry, Kautokeino, Norway, ${ }^{4}$ UIT Arctic University of Norway 
ontologies (also referred to as worldviews) interact and strive to sustain their own existence (Blaser 2009a,b, 2013, 2014, Escobar 2010, Oksala 2010). In the words of Oksala (2010:447), political ontology "concerns the contestation and struggle over the institution and disclosure of reality." Oksala (2010) argues that reality, as we know it, is constructed through social practices; it incorporates power relations and concrete struggles over truth and objectivity in social space. According to Blaser (2009b:11), ontologies "are not pregiven entities but rather the product of historically situated practices." As such, he situates the Eurocentered modernity as a particular worldview among many others, among them, indigenous ontologies (Blaser 2009a). However, the Euro-modern ontology is based on the idea of universalism; that only one reality, or one truth, exits (Blaser 2009a).

The ontological basis for decision making, whether it is acknowledged or unacknowledged, has "profound epistemological, methodological, and practical political consequences" (Hay 2006:79). In cases when those who govern do not acknowledge or are not aware of the alternative ontology of those being governed, conflicts arise (Blaser 2009a). Therefore, addressing competing ontologies could offer an approach to understand how socio-environmental conflicts emerge (Acuña 2015, Ruiz Serna and Del Cairo 2016).

Here, our work is based on a participatory study conducted by a team consisting of three scientists and four Sámi reindeer herders. The empirical data presented comes mainly from the participating herders' own life experiences. Through facilitated discussions, the whole study team engaged in the data analysis. Secondary sources, including government documents, were also used to inform the analysis. We first contextualize the study and introduce the concept of traditional knowledge. Thereafter, we describe the methods used before presenting the results and discussing the findings of the study. All quotations used here originating from Norwegian sources were translated by the authors.

\section{Contextualizing the study}

Reindeer husbandry is a livelihood among 24 different indigenous peoples living on the Arctic tundra and sub-Arctic taiga. Sámi reindeer husbandry is practiced in the area often referred to as Sápmi, the land of the Sámi people. Sápmi is a geographical area that covers the northern parts of Norway, Sweden, Finland, as well as the Kola Peninsula of the Russian Federation. The reindeer herding areas in Norway cover approximately $40 \%$ of the mainland, from Finnmark in the north to the counties of SørTrøndelag and Hedmark in the south. According to national legislation, only people of Sámi descent may own reindeer, with the exception of a few concessions in the south. Finnmark is Norway's northernmost county and largest reindeer-herding region. Roughly $70 \%$ of the approximately 210,000 semidomesticated reindeer and approximately $76 \%$ of the reindeer owners in Norway are registered in Finnmark. Approximately $55 \%$ of all reindeer and $62 \%$ of all reindeer owners in Finnmark are found in West Finnmark, making this the largest reindeer herding region in Norway (Landbruksdirektoratet 2016).

Here, we use the respective terms "reindeer husbandry" and "pastoralism," and "herder" and "pastoralist," interchangeably. Pastoralism is a form of animal husbandry especially adapted to marginal and unstable grazing resources (Pedersen and Benjaminsen 2008); it is a system based on extensive land use and often involves moving the herds between pastures as a way of coping with spatial and time variations in the grazing conditions in search of fresh pasture (Niamir-Fuller 2000, Dong et al. 2011). Sámi reindeer husbandry is a type pastoralism. In West Finnmark, the interior south is used as winter pastures, whereas the coastal areas are spring, summer, and autumn pastures. Most herds cross a number of municipalities on their migrations between winter and summer grazing areas. In Finnmark, the herds migrate up to $350 \mathrm{~km}$ between the inland and the coast (Magga et al. 2009).

Traditionally, the use of seasonal pastures and the division of labor are organized within siidas (Sara 2009). The concept of siida is known throughout Sápmi and can be loosely translated as "community" (Mustonen and Mustonen 2011, Sara 2013). In the West Finnmark pastoral context, siidas are kinship-based groups of herders and the customary management units within Sámi reindeer husbandry (Bjørklund 1990, Paine 1994). Although the reindeer are organized in siida herds, each animal is the private property of an individual owner. Traditionally, new-borns, males and females alike, are given a personal mark that is cut into the ears of the animals. Therefore, all individuals get a chance to develop their own herd. Also, after marrying, the tradition is that each spouse keeps ownership of their own reindeer and its offspring.

Key to the role of the siidas is dealing with issues related to "ecology, herding strategies, coordination of herding tasks, and relations to surrounding siida units" (Sara 2009:158). It is important to note, however, that siidas are not static organizations. Sara (2009:176) explains that every siida unit is continuously formed by ongoing practices and through the siidamembers' participation in daily discussions, actions, and evaluation in response to events and processes within the herd and the landscape in which they operate. As such, the siidas' practices are diversified by their distinct local adaptation and knowledge (Sara 2009).

\section{Traditional knowledge}

Díaz et al. (2015:13) define traditional knowledge as "[a] cumulative body of knowledge, practice and belief, evolving by adaptive processes and handed down through generations by cultural transmission, about the relationship of living beings (including humans) with one another and with their environment." In northern Sámi, a language spoken in northern Norway, northern Sweden, and northern Finland, "traditional knowledge" is translated as árbevirolaš máhttu or árbediehtu. According to Eira and Sara (2017), the concept of traditional knowledge is relatively new in the Sámi language, and its recent use stems from the need to articulate indigenous livelihoods and knowledge in relation to other forms of knowledge. The concept of árbediehtu contains practical knowledge and competence, as well as knowledge related to social relations as information exchange, consultation, participation, and discussion concerning both practical tasks and human-nature relationships (Eira and Sara 2017).

In the transfer and practice of knowledge, language is of particular importance; the Sámi herding language is systematic, specialized, and has a high level of precision for describing 
herding strategies, climatic conditions, land use, and the morphology, physiology, behavior, and ecology of reindeer (Eira 2012). Traditional Sámi reindeer herding knowledge is not static; it is constantly "carried out, tested, and renewed"(Sara 2009:175). Knowledge is developed based on the results from the continuous process of adapting to the surroundings. Through participation in daily life and the various chores throughout the year, the siida members acquire reindeer herding knowledge (Sara 2013, Eira et al. 2016). Therefore, a herder's knowledge reflects his or her position in the household and siida, the siida's adaptation to the landscape, its migration system, as well as the environment in which it operates (Eira et al. 2016).

Although there is a diversity of herding strategies and local knowledge within Sámi pastoralism in West Finnmark, the herding communities share cosmological perspectives on the human-nature relationship (Sara 2009, Eira et al. 2016). Sámi reindeer herders, as do many other indigenous peoples, have a broader understanding of the relationship between humans and nature than do Western scientists (Huntington et al. 2006, Berkes 2008, Díaz et al. 2015). While both national and international conventions (e.g., the Norwegian Nature Diversity Act and the Convention on Biological Diversity) recognize the role of traditional knowledge in achieving biodiversity conservation and sustainable development, there is a tendency among scientists and resource managers to assume that indigenous knowledge systems can be fully translated and integrated into the Western science knowledge system (Nadasdy 1999, Mistry and Berardi 2016). Blaser $(2009 b: 15)$ argues that there is a dominant trend within environmental governance that indigenous "knowledges and practices are translated into discrete packages" suitable for being incorporated in the existing toolkit of practitioners and decision makers. Nadasdy (1999) makes a similar argument. He also states that traditional knowledge should rather be understood as "one aspect of broader cultural processes that are embedded in complex networks of social relations, values, and practices which give them meaning" (Nadasdy 1999:5). Also, Huntington et al. (2006) emphasize the importance of listening to and understanding traditional knowledge statements "within a larger political, spiritual, and epistemological context."

\section{METHODS}

This work is based on a participatory study; that is, a bottom-up approach that focuses on locally defined priorities and perspectives, where the participants engage in mutual learning, analysis, and coproduction of knowledge (Cornwall and Jewkes 1995, Bergold and Thomas 2012). The study team included four Sámi pastoralists and three scientists (the authors). The participating herders were selected based on purposive sampling; that is, we identified the participants in a strategic way to ensure that they would be relevant to our research objective (Bryman 2012). They were selected according to the following criteria: members of reindeer herding families; practical experience in reindeer herding and husbandry in West Finnmark in the late 1950 s and 1960 s, as well as after the political reform; experience from participating in political bodies for reindeer husbandry; deep knowledge of and the ability to master and use reindeer herding terminology; and willingness to share views and reflections on changes to the governance of Sámi pastoralism. The selected group of participants consisted of one woman and three men between 65 and 78 years old, all spoke northern Sámi as their first language, and all had past experience in being part of scientific studies. The participants, who preferred to be anonymous, are referred to here as Participant 1, 2, 3, and 4.

The authors represented diverse science backgrounds (biology, linguistics, and environment and development studies). All have long experience (between 10 and 55 years) in working on issues related to reindeer husbandry. One of the scientists is part of a Sámi reindeer herding family in West Finnmark; the other two are non-Sámi, born and raised outside a Sámi community. The study team was large enough to ensure a variety of experiences and opinions and to enable collective recollection and reflection on past events, and was small enough to fit around a kitchen table and for all members to engage in the discussions. We emphasized creating an informal and dynamic atmosphere during the team gatherings, and we served coffee and food.

The study team met twice for half-day gatherings in July 2014 and March 2015. Both meetings were recorded, transcribed, and shared within the team. Prior to the gatherings, the authors defined topics for discussion. In reality, however, the discussions resembled a conversation among friends. We did not follow a strict step-by-step research approach but took a more organic approach in dealing with research questions. The team members were free to raise any issue they found relevant to the question of concern, to tell anecdotes and jokes, and to question one another's stories and arguments. The semistructured approach enabled in-depth explorations of issues that the participants found relevant to the topic of discussion. As such, another constellation of participants might have altered the focus of the discussions. Norwegian was the main language used during the discussions, but the participants also used Sámi language as a way to offer more precise descriptions. For the benefit of the two non-Sámi scientists, discussions in Sámi were translated immediately to maintain the flow of conversation.

During the first gathering, the topic for discussion was the political reform of reindeer husbandry in the 1970s, and how the new policies and regulations corresponded with the pastoralists' traditional herding practices and knowledge. Prior to the second gathering, the authors developed two future narratives describing two different governance structures for reindeer husbandry (see Box 1). Future narratives are a form of scenarios; they are qualitative descriptions of possible futures. Scenario analysis is a way of providing predictions for studying the future. There are three main categories of scenarios proposed for discussion: predictive (What will happen?), explorative (What can happen?) and normative (How can a specific target be reached?) (Börjeson et al. 2006:725). We used a set of explorative scenarios, which is, according to Börjeson et al. (2006:727), particularly useful in cases when the research participants "have fairly good knowledge regarding how the system works at present" and have an interest "in exploring the consequences of alternative developments." However, our purpose with the future narratives was not to determine probable future governance structures, but rather to establish a shared platform for the conversations within the study team. The issue addressed during the second meeting concerned what challenges the two future narratives would bring to Sámi reindeer husbandry. 


\section{Box 1:}

\section{Future Narrative X: State governance of reindeer husbandry}

Reindeer husbandry has become a state business. Advanced scientific models are used to calculate herd and slaughter strategies that will optimize meat production. The central authorities have limited the number of concessions for owning reindeer in West Finnmark to 200; no concession-holder can own $>500$ reindeer. Traditional earmarks are banned. Instead, all reindeer are marked with an electronic ear-chip and a GPS, which give herders and the state full control of the whereabouts and the behavior of all domesticated reindeer. Pastures are commonly fenced, and therefore, land-use conflicts between pastoralists, conservationists, and the sedentary population are minimized. The workload within reindeer husbandry is reduced because of changes in practices: extensive use of animal transportation and fences; common use of year-round pastures; and use of GPS and drones to monitor the herds. The concession-holders receive a monthly salary from the state for producing meat and maintaining Sámi reindeer husbandry.

Future Narrative Y: Siida governance of reindeer husbandry

The concession system is abolished, and the state subsidies for reindeer husbandry are terminated. The siidas regulate herds, land use, and recruitment. Reindeer number and herd structure vary among siidas according to climate and weather conditions, available pastures, markets, and preferences. Siida decisions are based on a combination of traditional knowledge, science, and modern technology. Many siidas have their own mobile slaughter vehicle, and meat products are one of many income sources from the reindeer. Meat, antlers, skins, organs, and duodji (traditional Sámi handicraft) are other products sold within Norway and exported. More people make a living from reindeer husbandry; many of these combine pastoralism and other types of paid work.

The first narrative (called Future Narrative X; Box 1) describes a governance regime with more state control, implying more detailed regulation of reindeer husbandry; the second narrative (called Future Narrative Y; Box 1) describes a decentralized governance structure in which the pastoralists have more internal control, implying little state regulation and a strengthening of the traditional siida institution. The scenarios were informed by the accounts made by the research participants during the first gathering, conversations with other pastoralists, as well as statements made by government officials on preferred herding practices. The narratives were exaggerated scenarios, which represented two "opposite" futures for Sámi pastoralism in which pastoralists' knowledge and worldviews played different roles. The geographical scope of the two narratives was West Finnmark, and the starting point was the year 2035. The narratives described some key aspects (Börjeson et al. 2006) of the governance of reindeer husbandry raised by the participants during the first gathering of the study team: regulation of pastoralists and reindeer, herd structure, pasture management, herding practices, production, and decision making.
The future narratives were presented and discussed at the second gathering of the study team ${ }^{[2]}$ and used as a tool to stimulate engagement and reflections on traditional Sámi reindeer herding knowledge and worldview (see e.g., Lynam et al. 2007, OterosRozas et al. 2015 for more on participatory scenario methods). Inspired by Paschen and Ison (2014), we sought to facilitate reflective colearning through "story-telling." Paschen and Ison (2014:1086) explain that individuals interpret scenarios based on their own knowledge, values, and worldviews. As the participants communicate their interpretations, they use their own words (their own stories) to "re-work and order experience, evaluate events and construct meaning and knowledge." As such, the empirical data presented here come mainly from the participating herders' own life experiences. Through the facilitated discussions, the whole study team engaged in data analysis.

In addition to the discussions with the four selected pastoralists, the study was informed by secondary sources such as policy and government reports, in addition to scholarly publications.

\section{RESULTS}

\section{Knowledge base for the state-driven rationalization of Sámi reindeer husbandry}

In 1946, ethnographer Ørnulf Vorren, published an article about reindeer husbandry in Norway in which he argued the need for radical modernization and rationalization of Sámi herding practices. Vorren observed that in West Finnmark, the whole family still migrated with the herd throughout the year, as in older times. The scientist stated that the practices of the herders in this region were "out of date" (Vorren 1946:217). He argued that "if this source of livelihood is not to be lost," the herders needed to alter their nomadic lifestyle and become more "modern" and "rational" like reindeer herders had done in other places in Norway (Vorren 1946:220).

Twenty years later, a consultative committee (established to revise the Reindeer Husbandry Act of 1933) acknowledged that the reindeer industry had not progressed at the same pace as the rest of society in Norway (Landbruksdepartementet 1966). Like Vorren, the committee argued that reindeer pastoralism had to change. It claimed that reindeer pastoralism could be safeguarded by very rapid development, development similar to what it took agriculture several generations to achieve (Hætta et al. 1994). The committee recommended engaging science and innovation to modify and adjust the old traditions and practices of reindeer husbandry (Storli and Sara 1997). Accordingly, scholarly experts, rather than practitioners, were appointed as advisors on the development process (Paine 1994, Riseth 2000).

The state authorities' perception of Sámi reindeer husbandry reflected a global discourse that holds an understanding of traditional pastoralism as economically irrational (Benjaminsen and Svarstad 2010). The authorities were concerned that there were too many reindeer and too many herders degrading the pastures and jeopardizing the economic development of Sámi reindeer husbandry. Thus, science on how to optimize reindeer meat production through optimal herd structure (i.e., the distribution of the animals' weight, sex, and age) and an optimal harvest strategy (i.e., autumn calf slaughter) informed the value and knowledge base for the development of policies (see e.g., Lenvik 1988 for an elaboration on optimizing meat production). 
In the late 1970s, new policies for reindeer husbandry were introduced. The political reform was catalyzed through two main instruments for optimizing meat production and increasing the income and welfare of pastoralists (Landbruksdepartementet 1976a,b): The Agreement on Reindeer Husbandry, established in 1976, and the Reindeer Husbandry Act of 1978.

The Agreement on Reindeer Husbandry between the state and the herders' association described monetary transfers to the industry "on the understanding that the rationality and efficiency of production" was ensured (Paine 1994:159, emphasis original). The economic incentives promoted an increase in calf slaughter and stimulated a higher ratio of female reindeer in the herds as way to increase calf production. Subsidies were provided for infrastructure investments (e.g., vehicles and fences) to increase the efficiency of the herders. The herders were encouraged to concentrate on producing meat; the responsibility for slaughtering, processing, trading, and marketing was transferred from the pastoralists themselves to certified slaughterhouses and the Norwegian meat cooperative (Norges Kjott og Fleskesentral, currently named Nortura; Sagelvmo 2004, Reinert 2006).

Whereas the Reindeer Husbandry Act of 1933 had the objective to control the herders' use of pastures to avoid land-use conflicts between herders and farmers, the Reindeer Husbandry Act of 1978 aimed at steering the development of Sámi pastoralism in a particular direction (Bjørklund 2016). The new policies introduced a concession system to control the number of herders and reindeer, and the national reindeer husbandry administration was mandated to educate, guide, and advise herders on best practices (Landbruksdepartementet 1976a).

Since the 1970s, the state's governance regime for Sámi reindeer husbandry has been revised in several ways. For example, the current Reindeer Husbandry Act of 2007 introduced tools for increased internal self-governance (internt selvstyre) within the herding districts (Landbruks- og matdepartementet and Reindriftsforvaltningen 2007). Herding districts are state-defined administrative units with the responsibility for managing internal issues and attending to the interests of the members in relation to the larger society. In some cases, the herding district corresponds with a siida unit; more often, a district comprises a number of siidas. The main tool for self-governance was the internal management plans (bruksregler), which were to be developed and implemented by each herding district. The internal management plans were to include descriptions of the use of seasonal pasture and the timing of this usage and to set an upper reindeer number for the herding district. Further, the plans were supposed to be developed by integrating state regulations and "traditional use" of pastures (Reindriftsforvaltningen 2009).

Since the end of the 1970s, the notion of "sustainability" has entered the public debate and become a political priority, but the overarching objective of the policies is still to rationalize Sámi pastoralism. Current policy documents declare that the main goal is to "develop reindeer husbandry into a rational market-oriented industry that will be sustainable in the long term" (Landbruksog matdepartementet 2017). Also, today, the policies are informed by science on how to optimize reindeer meat production. Since the 1970s, the mathematical models for optimization have been further developed through a number of studies on the relationship between the weight of individual animals and the density of reindeer on the pasture (see e.g., Lenvik 1990, Ims and Kosmo 2001, Fauchald et al. 2004, Tveraa et al. 2007, Bårdsen and Tveraa 2012). Based on these studies, government officials have identified targets for "proper" carcass weights, reindeer numbers, and animal densities (see Reindriftsstyret 2011, 2012). The herding districts are required to adopt herding practices and develop internal management plans that will ensure these targets. The targets are further used as indicators to assess whether the plans and practices of the herding districts are sustainable. Those who do not operate within the defined targets are sanctioned by reduced subsidies or through fines.

\section{Traditional Sámi reindeer herding knowledge}

The government officials' standardized indicators for sustainable reindeer management stand in contrast to the research participants' perspectives on "proper" reindeer management. The participants argued that because of the unpredictable and changing nature of West Finnmark, the focus of herders is to seek balance in the relationship between nature, reindeer, and humans. They explained that this balance is constantly challenged by spatial and temporal variations in weather and predators. Therefore, any herder's understanding of a "rational" and "sustainable" reindeer number and herd structure would depend on the local climate, landscape, grazing conditions, predators, and other types of disturbances. The participants claimed that the government officials' use of indicators did not take into account the local specifics of herding and production strategies and made it difficult for herders to adapt to local realities. Participant 1 said, "People believe that reindeer husbandry is the same everywhere, but they are misinformed."

According to the participants, balance in the relationship between nature, reindeer, and humans can be enhanced by maintaining flexibility within reindeer husbandry. They described three essential and interlinked techniques for maintaining flexibility: observation, mobility, and the maintenance of "buffers."

First, they mentioned the value of constantly observing the herd and the landscape. Through observations, herders can monitor the well-being of the animals in the herd and on the land. Rather than use carcass weights and density as indicators for well-being, herders would observe the behavior of the animals and the hair quality, antlers, and body condition of living animals to gain information about the health and function of the animals in the herd. Through long-time observations of the herd, they would also learn to recognize and interpret individual reindeer.

Second, the participants talked about mobility as an essential capacity for Sámi reindeer and pasture management, that is, moving with the herd to observe the reindeer and to ensure the herd's well-being. Participant 1 expressed this idea by quoting a Sámi proverb: Mana lea buoret go oru (Better to be on the move than to be in one place). Participant 2 argued that reindeer have strong instincts, "In the spring, they want to move northwards, and there is no way you can hold them back," unless the herd is within fences. Traditional Sámi reindeer herding knowledge informs the pastoralist about how and where to move the herd during johtit (the seasonal migration between pastures) and sirdit (movements within a pasture), and how to avoid stray animals. However, the state requirement to set fixed dates for the herds' entrance to and exit from seasonal pastures, combined with increasing loss of pastures to competing land-use interests in West 
Finnmark, decreases the mobility and thereby the flexibility in reindeer husbandry.

The participants argued that the combination of long-term observations and mobility enables herders to control and facilitate the herd, as well as maintain its productivity. For example, they explained that pastoralists that monitored their herd carefully would be able to recognize a sáhkkonálli (a female that gives birth to healthy calves every year, even when the grazing conditions are difficult). Some sáhkkonálli tend to produce female calves, and these animals are considered especially valuable. Participant 2 argued that pastoralists without proper observation skills might slaughter a sáhkkonálli because he or she would not be able to identify an animal with the desired qualities. Without traditional Sámi reindeer herding knowledge (e.g., about production, mobility, and monitoring), the participants argued, pastoralists would not be able to obtain the information needed to build a robust and productive herd from just a few animals. Pastoralists would not have the skills to keep the animals together as a herd or maintain flexible herding practices.

A third technique to maintain balance in the relationship between nature, reindeer, and humans is to keep buffers within the herd, the pastures, and the labor force. According to Participant 3, a buffer is a measure to increase the resilience of reindeer husbandry in a reality of unpredictable environmental changes. For example, it is important to keep more reindeer than "needed" because "there are always losses in reindeer husbandry," this participant explained. According to him, it is essential to find a balance where "you do not reduce [slaughter] too much and avoid too many losses" of animals. Likewise, having access to buffer pastures ensures access to alternative grazing in times when the regular pastures are unavailable because of extreme weather conditions or other reasons. The buffer labor force consists of reindeer owners and family members who do not herd on a daily basis but who help out in the more labor-intensive periods of reindeer husbandry; for example, migration, ear marking, and rounding up the animals for slaughter.

\section{Conflicting knowledge systems}

There are many examples of decision-making processes in which traditional Sámi reindeer herding knowledge and Western science compete to define "proper" reindeer management and herding practices. A case that has received a lot of attention, and which was also raised by the research participants, is the recent destocking of herds in West Finnmark. The Reindeer Husbandry Act of 2007 (hereafter referred to as the 2007 Act) introduced internal management plans as a tool for increased internal selfgovernance within the herding districts and as a measure that would support traditional pasture management (Reindriftsforvaltningen 2009). The main concern of the governance officials was the number of reindeer, especially in Finnmark. Therefore, the state issued guidelines to assist the herders in defining a sustainable reindeer number for their internal management plans. The report proposed quantitative and standardized targets based on carcass weights and production volumes; it presented traditional indicators for assessing the well-being of the herd as supplementary and voluntary (Landbruks- og matdepartementet 2008). The national Reindeer Husbandry Board, which manages reindeer husbandry on a national level, including the regulation of reindeer numbers, reviewed the herders' proposals for upper reindeer numbers and emphasized the quantitative and standardized indicators, which they regarded as more objective, and thus, more true (Johnsen et al. 2015, Johnsen 2016). Consequently, in the decision making regarding reindeer numbers in West Finnmark, traditional Sámi reindeer herding knowledge was commonly ignored.

The participants argued that the practical implementation of policies eroded, rather than sustained, traditional Sámi reindeer herding knowledge. They explained that the problem was not only the state-defined indicators used to assess sustainable reindeer numbers. The state requirement to have fixed dates for the herds' entrance to and exit from seasonal pastures also discouraged herders from making management plans based on their own traditional and experience-based knowledge. The subsidy system embodies other challenges. According to the participants, the state regulations stimulated a transfer from Sámi to "Norwegian" reindeer husbandry. They referred to public seminars on sustainable reindeer husbandry where scientists, and what they referred to as "Norwegianized" herders, lectured on "rational" herding practices. Participant 1 said, "A dáža [a Norwegian person or Norwegian manner, style, or ways (Nielsen 1979)] teaching reindeer herders about reindeer husbandry? It's just not right!" Also, a recently published "white paper" on reindeer husbandry (Landbruks- og matdepartementet 2017) has been criticized by the leader of the reindeer herders' association (Jåma 2017) and others as a continuation of the "Norwegianization" of Sámi pastoralism.

Despite their opposition to the state presentation of what reindeer husbandry ought to be, the participants acknowledged that for many herders, it was rather comfortable to be part of the state's knowledge and governance system because it gave access to subsidies. The subsidies have become an important source of income for many Sámi pastoralists. However, the participants feared that over time, the economic incentives would lead more and more pastoralists to adopt the state's standardized and quantitative perception of rational practices. They were concerned that the state governance of Sámi pastoralism would erode the traditional knowledge about how to develop a robust and productive herd and that new generations of pastoralists would only learn the state's understanding of "proper" herd structures and harvesting strategies. The participants worried that the traditional reindeer herding knowledge would disappear with the older generation because this would mean the end of Sámi pastoralism, and with it, the knowledge about how to recognize the features and functions of animals, including recognizing a sáhkkonálli.

Discussing the outlook for reindeer husbandry, the participants were concerned that a future with more state regulations and control (as described in Future Narrative $\mathrm{X}$ ) would value technological skills as more important than the capacity to observe reindeer and the landscape. They worried that more use of GPS, electronic ear-chips, and drones instead of spending time with the herd; transportation of animals or all-year pastures instead of migration between seasonal pastures; and additional feeding and fences instead of moving the herd to the most suitable pastures, would further weaken herders' ability to maintain traditional knowledge about ways to enhance flexibility in reindeer husbandry and balance in the relationship between 
nature, reindeer, and humans. However, despite this concern, the participants were not able to imagine any future scenario where traditional Sámi reindeer herding knowledge would be totally redundant. For example, Participant 1 acknowledged that although there could be some areas suitable for all-year pastures, most of West Finnmark would not be suitable for all-year use. She stated that it would be impossible to keep the herd in one place throughout the year without extensive use of fenced pastures. Further, she said, keeping the reindeer within fences over long periods would violate the welfare of the reindeer because this would prevent them from escaping insects or finding preferred forage.

The participants claimed that because of the challenging climate and geography of West Finnmark, traditional knowledge has, and will continue to have, a vital role in reindeer husbandry in this region. As such, they stated that those herders who were able to maintain traditional Sámi reindeer herding knowledge would have a competitive advantage because they would know how to avoid losing animals in times of unfavorable grazing conditions. The participants acknowledged that more extensive use of GPS and drones could make it easier to monitor the herd remotely; they claimed, however, that technology could not substitute the added value of being and moving with the herd. Technology could not protect reindeer from predators, prevent animals straying, or ensure the well-being of the herd, they argued.

When discussing a future in which the state no longer governs Sámi pastoralism, and the siidas have full autonomy (as described by Future Narrative Y), the participants acknowledged that this scenario would also create challenges. For example, if the subsidy system ceased to exist, this would have a large impact on herders' income. Many herders would have to find income sources outside reindeer husbandry. However, the participants preferred this scenario because it would allow the siidas the freedom to establish herd structures and production strategies adjusted to their pastures and preferences. Management plans could be made by combining herding knowledge, science, and technology as the herders found appropriate. The participants recognized that also with full siida autonomy, there would likely be some herders that would choose to operate in line with the state perspective of sustainable pastoralism, but only if they found it economically viable without state subsidies. However, traditional Sámi reindeer herding knowledge, for example, about the sáhkkonálli, would be vital for the economy of all herders, they claimed.

\section{Competing worldviews}

The participants' discussions about traditional knowledge triggered a debate about pastoral worldviews, identity, and rights. For example, the participants stated that more state regulations (as described in Future Narrative X) would be a threat to Sámi pastoral lifestyle, culture, and ethical perspectives concerning the reindeer and nature. An element of Future Narrative $X$ that was discussed extensively in this regard was the banning of the traditional cutting marks in the ears of the reindeer as a way to indicate the owner of the animal. The participants argued that for Sámi pastoralists, an earmark did not only represent private property, it also symbolized skills, rights, and identity. Participant 2 explained that if one comes across a group of reindeer without earmarks after the earmarking season, this is an indication that a herder has lost control of his or her animals; in other words, it indicates a herder without "proper" herding skills. The participants explained that according to Sámi customs, geažotbeallji (a reindeer without earmarks) is seen as potentially belonging to anyone. Therefore, it can be earmarked by any herder who finds it. Further, without a herd (a group of earmarked animals), it is difficult for a pastoralist to claim the right to pastures because the right to land, as acknowledged by national and international law, is tied to the customary use of the landscape. As such, a personal earmark embodies an individual right to own reindeer, and owning reindeer gives the possibility of engaging in pastoralism, developing a herd, and prescribing rights to land. Participant 2 said, "Do you know what it means to abolish the earmarks? It means removing the Sámi’s heart. ... I would lose my identity and everything."

Although the participants emphasized "proper" herding skills as a criterion for succeeding as a pastoralist, the participants also acknowledged nature as an actor that influences the survival rate and production of the herd. For example, Participant 4 explained that a herder would not be able to increase his or her reindeer number unless nature "gives," that is, allows the growth to happen. In this regard, he claimed, the state's current use of standardized targets for sustainable animal weight and density have no practical value because it is nature that determines the production of a herd. Herders should not degrade the pastures, he argued; however, if a herder is able to maintain a herd size beyond what the state has defined as sustainable, this must mean that the herd size is within the limit of nature. Further, the participants stated that the standardized targets did not acknowledge the variability and unpredictability of nature and the consequent variation in animal survival and calf production from year to year. The irregularity of nature is well recognized by herders in West Finnmark and captured in the Sámi proverb jahki ii leat jagi viellja (this year is not last year's brother).

The participants mentioned the landscape as another factor that influences the size and production of the herd. Participant 2 said, "It is the landscape that shapes the reindeer." The participants explained that some landscapes produce small reindeer. They referred to areas in West Finnmark where the state-set targets for carcass weights could not be reached, even when the density of animals was way below what the state considers sustainable.

Yet another factor that the participants recognized as essential for being a successful herder was boazolihkku ("reindeer luck"). According to Oskal (2000:176), reindeer luck is a state in which the herd grows, that is, when the females produce calves and the herd survives predators and avoids difficult snow conditions. Oskal explains that the path to reindeer luck is to live in accordance with certain ethics, for example, to refrain from complaining about or celebrating one's reindeer number; to use slaughtered animals fully; and to get along with neighboring herders, the reindeer, pastures, and the landscape. The latter includes asking spirits for permission to enter or camp in an area. Oskal (2000:179) says that according to the Sámi pastoral worldview, reindeer herders "should not conquer the world but try to get along with it and come to an understanding with it."

The participants explained that the reindeer has its own needs; rather than fully controlling the herd, the pastoralists' role is to respect the nature of the reindeer and facilitate its biological needs. The Sámi perception of the reindeer as a free animal has been 
elaborated by Sara (2009). He explains that within Sámi ontology, the reindeer is an actor inside the siida system; it "chooses its own movements and course of life" (Sara 2009:173). As such, humans can never obtain complete control over the reindeer. The reindeer belongs to the landscape where, according to pastoralists' worldview, it is free, mobile, and independent (Bull et al. 2001:300). The Sámi myth of the origin of reindeer herding emphasizes a voluntary companionship between humans and reindeer, and herders often refer to reindeer as "a good governed by the wind" (Sara 2009:171-172). Therefore, the pastoralists' exercise of control over the reindeer should be understood as a compromise based on the herders' knowledge of and respect for the animals' needs and nature (Sara 2009).

\section{DISCUSSION}

Comparing the state's and the research participant's knowledge base for understanding reindeer husbandry shows two very different perspectives on what Sámi pastoralism is and ought to be (conflicting views on reindeer husbandry are also presented in previous research; see, for example, Bjørklund and Brantenberg 1981, Paine 1994, Turi and Keskitalo 2014, Benjaminsen et al. 2015, 2016, Johnsen and Benjaminsen 2017). The traditional Sámi pastoral way of understanding reindeer husbandry with a focus on maintaining flexibility stands in contrast to the positivistreductionist approach in Western science that dominates contemporary resource management. The latter approach has synthesized knowledge about the world into generalizations independent of context, space, and time (Berkes 2008). The standardized targets for carcass weight and density are simplified generalizations that make the reindeer sector more manageable for the state; however, these simplifications leave little room for the herders' complex, situated, and local knowledge of reindeer and pastures (Johnsen et al. 2015, Benjaminsen et al. 2016).

Herding practices based on a rationale that emphasizes the agency of reindeer and nature stands in deep contrast to the state governance of reindeer husbandry, which requires pastoralists to control the herd size and whereabouts of the animals at all times. Where the participants see reindeer husbandry as a humananimal-nature relationship, state policies reflect an understanding of reindeer as objects that can be manipulated to produce maximum amounts of meat through streamlined herding practices. We find that the pastoralists and the state operate within two different ontologies that compete to define sustainable, rational, and proper reindeer husbandry.

Similar situations are found in other parts of the world. For example, Natcher (2000) observes that a barrier to comanagement of land and resources in the Province of Alberta, Canada was the conflicting worldviews between provincial authorities and the Whitefish Lake First Nation: While the authorities viewed the future as predictable and wildlife as an entity that could be manipulated, the First Nation community perceived the future as uncertain and beyond human control. According to the latter group, the idea of planning the future could jeopardize the relationship between the human and nonhuman worlds (Natcher 2000). Another example derives from the research of Blaser $(2009 b)$ on hunting practices and local wildlife management among the Yshiro people in Paraguay. Blaser (2009b) finds that though the local authorities were concerned that the Yshiro actions corresponded with the biologists' conservation agenda, the authorities did not regard the Yshiro rationale for management practices as relevant for the protection of wildlife. We find that authorities in Norway have a similar attitude toward herders' knowledge base and rationale for reindeer husbandry. For example, the working group that drafted the 2007 Act mentioned the concept of reindeer luck (see NOU 2001:321), but they did not problematize the concept in terms of the policies they were drafting. Also, the internal management plans introduced by the 2007 Act were presented as a tool for self-governance and an approach to integrate state regulations and traditional pasture management, but in practice, the herders had to apply Western science-based targets for sustainable reindeer husbandry when developing the plans.

This lack of acknowledgement of Sámi reindeer herding knowledge and worldviews stands in contrast to Norway's recognition of indigenous peoples' rights. Since 1988, the Norwegian Constitution has stated, "[t]he authorities of the state shall create conditions enabling the Sámi people to preserve and develop its language, culture and way of life" (§108). In 1990, Norway was the first country to ratify the Convention Concerning Indigenous and Tribal Peoples in Independent Countries (often referred to as ILO Convention 169), which recognizes indigenous peoples' rights to exercise control over their own institutions, ways of life, and economic development. Despite 30 years of recognition of the right to a Sámi way of life, it is not clear how the right could or should be translated into practical politics (realpolitik; Bjørklund 2013, Ravna 2015).

In April 2017, the Ministry of Food and Agriculture launched a new "white paper" on Sámi reindeer husbandry (Landbruks- og matdepartementet 2017). At a public hearing shortly after, the Sámi Parliament, the Sámi Reindeer Herders' Association, and representatives of various herding districts criticized the "white paper" for having a poor knowledge base and embodying a continuation of the "Norwegianization" of Sámi reindeer husbandry, which started with the political reform of the 1970s. The issue of "Norwegianization" of the Sámi population (all Sámi, not only herders) is receiving increasing attention in the public debate. In June 2017, the national Parliament approved the establishment of a commission to examine the "Norwegianization" of Sámi (and Kven, an ethnic minority who are descended from Finnish peasants and fishermen who migrated to northern Norway during the 18th and 19th centuries; Kontroll- og konstitusjonskomiteen 2017, Larsson et al. 2017). The commission is yet to be established, and its scope is still to be defined.

Though the recognition of traditional knowledge has increased within the Western research community, this recognition tends to be related to aspects of traditional knowledge that either resemble data generated by scientific methods or provide baseline data in areas where Western scientific data are lacking (Simpson 2004). Most work in the field of traditional knowledge concerns collecting and documenting information, and there is little focus on finding meaningful ways to apply this information (Blaser et al. 2004). Because of the asymmetrical power relations between the knowledge systems, attempts to integrate traditional and scientific knowledge have translated into assimilation of the traditional into the dominant system (Nadasdy 1999, 2005, Blaser et al. 2004, Mistry and Berardi 2016). Nadasdy (1999:5) argues 
that the consequence of this integration is that traditional knowledge "must be expressed in forms that are compatible with the already existing institutions and processes of scientific resource management."

According to Mistry and Berardi (2016), knowledge integration is a way to institutionalize indigenous knowledge into existing environmental governance structures dominated by incentiveand market-based approaches to management. Thus, the integration serves to sustain existing power relations between scientists and resource managers on the one hand, and indigenous peoples on the other hand (Nadasdy 1999). When the use and application of indigenous knowledge are determined by Western science, the danger is that the "indigenous knowledge will change in its use and application, and, most critically, in its ability to deal with complexity," Mistry and Berardi (2016:1275) argue. Therefore, rather than facilitating participation and selfgovernance, the approach to knowledge integration risks further marginalization of indigenous people (Mistry and Berardi 2016). Recognizing the asymmetrical power relations between the knowledge systems, Díaz et al. (2015:10) suggest an approach to environmental understanding that embraces the "complementarity, synergy and cross-fertilization of knowledge systems, rather than the integration of one system into another."

Referring to the French philosopher Michel Foucault's work on the power-truth-knowledge complex, Peet and Hartwick (2009) argue that modern Western science has become dominant in the field of defining reason. They explain that this particular form of science, through its power of domination, classifies and thereby regulates "all forms of experience, interpretation, and understanding" (Peet and Hartwick 2009:204). However, while the Western understanding of the world has become hegemonic and is often taken as a truth, it is not always evidence-based. For example, Cleaver (2012:155) observes that policy making "is shaped by underlying worldviews which often reflect structural allocations of power and resources in society." There is, she argues, a need to recognize the worldviews that shape the models of governance.

Moreover, Blaser (2009b:16) argues that the Western understanding of the world "sustains itself through performances that tend to suppress or contain the enactment of other possible worlds." Recognizing this, Acuña (2015) and Ruiz Serna and Del Cairo (2016) argue that addressing competing ontologies could offer an approach to understand how socio-environmental conflicts emerge. Socio-environmental conflicts are often interpreted as problems of governance (e.g., lack of formal political participation or transparency); however, they could also be regarded as arising from a community's want to preserve culture and the environment (Acuña 2015). For example, Western ontology makes a distinction between nature and society (Latour 1993) and holds a notion of progress that includes human conquest of nature, industrialization, material abundance through superior technology, and economic development (Norgaard 2006). However, where Western ontology sees nature as an object that must be appropriated and exploited through privately owned entitlements, indigenous ontologies see the natural environment as an entity that "constitutes their territory and includes earth-beings who must be respected" (Acuña 2015:86). According to indigenous ontologies, a more appropriate way to understand people's relation with nature is that people belong to the land rather than the other way around (Blaser 2009a:891).

The taken-for-granted nature/culture and object/subject divides of "modernity" suppress subaltern ontologies and knowledge (Escobar 2010): The political ontology of Sámi reindeer husbandry concerns a struggle for recognition between two competing, but not equal, rationales for sustainable pastoralism. Because of an asymmetrical power relation between Sámi ontology and the dominant "modern" ontology, the former is suppressed by the latter. Our study shows however, that despite 40 years of state-effort to "rationalize" reindeer husbandry according to a Western worldview, traditional Sámi reindeer herding knowledge and ontology continue to play an important role in herders' narratives about what reindeer husbandry is and ought to be.

\section{CONCLUSION}

Using a participatory research approach, we examined how herders and government officials explained what reindeer husbandry is and ought to be and their conceptions of "proper" management techniques for reindeer, herders, and the land on which reindeer pastoralism depends. We find that the state policies for reindeer husbandry since the end of the 1970s promoted herding practices primarily based on Western knowledge and understanding of rational and sustainable herding practices. Science on how to optimize reindeer meat production through optimal herd structures, harvest strategies, and sustainable reindeer numbers still informs the values and knowledge bases for policies. Government officials use carcass weights, reindeer numbers, and reindeer density as indicators for assessing the sustainability of the herding districts' practices.

The positivist-reductionist approach in Western science that dominates contemporary resource management stands in contrast to the traditional Sámi pastoral way of understanding reindeer husbandry. The research participants emphasized the herders' objective to seek balance in the relationship between nature, reindeer, and humans. This balance is constantly challenged by spatial and temporal variations in weather and predators in West Finnmark. Therefore, any herder's understanding of a rational and sustainable reindeer number and herd structure would depend on the local climate, landscape, grazing conditions, predators, and other types of disturbances. The way to cope with these variations is to maintain flexibility in herding and husbandry. Flexibility is sustained through observing the herd, the landscape, and the climate; by moving the herd; and by keeping buffers.

We find that the state focus on meat production and its need for control, combined with its persistence in disseminating "proper" herding practices, marginalize the herders' context-dependent knowledge about how to adapt to an unpredictable and changing environment. Further, our analysis shows that the state and research participants had competing ways to perceive the world (ontological differences). While the state sees reindeer as an object that can and should be controlled by humans, the participants held an alternative understanding of reindeer and nature and how these should be governed. They saw the reindeer and nature as actors that should to be treated in accordance with certain ethics. 
Despite 40 years of policies attempting to transform and "modernize" reindeer husbandry according to the state's perception of "proper" pastoralism, we find that in West Finnmark, traditional herding knowledge and Sámi ontology continue to play an important role in pastoral practices and ethics. According to the research participants, it is likely that the traditional Sámi reindeer herding knowledge will play an important role in reindeer husbandry also in the future, independent of whether the future brings stricter state regulations or the responsibility of reindeer and pasture management is handed over to the siidas. Traditional herding knowledge, for example, how to recognize a sáhkkonálli and select the best animals to build a robust herd that is suited to the local landscape, will continue to provide a competitive advantage within the pastoral community, they claimed.

However, although the participants were optimistic about the role of traditional herding knowledge in the future, the reality is that traditional knowledge and worldviews are not acknowledged by the current policies and regulations governing Sámi pastoralism. Rather, the current governance regime undermines the code of conduct of the Sámi herding practices. Moreover, we have shown that the conflicting, asymmetrical knowledge systems and competing worldviews of what reindeer husbandry is and ought to be compromise the identity and rights of the pastoralists.

${ }^{[1]}$ In 1966, a consultative committee, established to revise the Reindeer Husbandry Act of 1933, submitted their recommendations for revised policies (Landbruksdepartementet 1966).

${ }^{[2]}$ One of the pastoralists (Participant 3) was prevented from participating at this gathering.

Responses to this article can be read online at: http://www.ecologyandsociety.org/issues/responses. php/9786

\section{Acknowledgments:}

This study is part of the projects titled, "The economics and landuse conflicts in Sámi reindeer herding in Finnmark: exploring the alternatives" (Dávggas) and "Rapid change - challenges or opportunities for sustainable reindeer husbandry" (Rievdan), both supported by the Research Council of Norway (grants 215961 and 238326, respectively). We express our appreciation of the research participants who shared their time, experiences, and perspectives with us. They preferred to be anonymous. We thank Tor A. Benjaminsen and Mikkel Nils Sara for their advice and three anonymous reviewers for their constructive comments and suggestions that helped improve the manuscript. Any remaining errors are ours. Ethics statement: The study was conducted in line with the Guidelines for Research Ethics in the Social Sciences, Humanities, Law and Theology (NESH 2016) and the Ethical Guidelines for Handling Traditional Knowledge at the International Centre for Reindeer Husbandry (ICR 2006).

\section{LITERATURE CITED}

Acuña, R. M. 2015. The politics of extractive governance: indigenous peoples and socio-environmental conflicts. Extractive Industries and Society 2(1):85-92. http://dx.doi.org/10.1016/j. exis.2014.11.007

Bårdsen, B.-J., and T. Tveraa. 2012. Density-dependence vs. density-independence - linking reproductive allocation to population abundance and vegetation greenness. Journal of Animal Ecology 81(2):364-376. http://dx.doi.org/10.1111/ j.1365-2656.2011.01913.X

Benjaminsen, T. A., I. M. G. Eira, and M. N. Sara, editors. 2016. Samisk reindrift, norske myter. Fagbokforlaget, Bergen, Norway.

Benjaminsen, T. A., H. Reinert, E. Sjaastad, and M. N. Sara. 2015. Misreading the Arctic landscape: a political ecology of reindeer, carrying capacities, and overstocking in Finnmark, Norway. Norsk Geografisk Tidsskrift - Norwegian Journal of Geography 69(4):219-229. http://dx.doi.org/10.1080/00291951.2$\underline{015.1031274}$

Benjaminsen, T. A., and H. Svarstad. 2010. Politisk økologi: miljø, mennesker og makt. Universitetsforlaget, Oslo, Norway.

Bergold, J., and S. Thomas. 2012. Participatory research methods: a methodological approach in motion. Forum Qualitative Sozialforschung / Forum: Qualitative Social Research 13(1):30. [online] URL: http://www.qualitative-research.net/index.php/ fqs/article/view/1801/3334

Berkes, F. 2008. Sacred ecology. Second edition. Routledge, New York, New York, USA.

Bjørklund, I. 1990. Sami reindeer pastoralism as an indigenous resource management system in northern Norway: a contribution to the common property debate. Development and Change 21 (1):75-86. http://dx.doi.org/10.1111/j.1467-7660.1990.tb00368.x

Bjørklund, I. 2013. Gruvedrift og reindrift - om nordområdesatsing, folkerett og trojanske hester i Sápmi. Pages 417-428 in S. Jentoft, J.-I. Nergård, and K. A. Røvik, editors. Hvor går Nord-Norge? Politiske tidslinjer. Orkana akademisk, Stamsund, Norway.

Bjørklund, I. 2016. Fra formynder til forhandler: om inngrep, konsekvensanalyser og 'balansert sameksistens'. Pages 177-193 in T. A. Benjaminsen, I. M. G. Eira, and M. N. Sara, editors Samisk reindrift, norske myter. Fagbokforlaget, Bergen, Norway.

Bjørklund, I., and T. Brantenberg. 1981. Samisk reindrift-norske inngrep: om Altaelva, reindrift og samisk kultur. Universitetsforlaget, Tromsø, Norway.

Blaser, M. 2009a. Political ontology: cultural studies without 'cultures'? Cultural Studies 23(5-6):873-896. http://dx.doi. org/10.1080/09502380903208023

Blaser, M. 2009b. The threat of the Yrmo: the political ontology of a sustainable hunting program. American Anthropologist 111 (1):10-20. http://dx.doi.org/10.1111/j.1548-1433.2009.01073.x

Blaser, M. 2013. Ontological conflicts and the stories of peoples in spite of Europe: toward a conversation on political ontology. Current Anthropology 54(5):547-568. http://dx.doi.org/10.1086/672270 
Blaser, M. 2014. Ontology and indigeneity: on the political ontology of heterogeneous assemblages. Cultural Geographies 21 (1):49-58. http://dx.doi.org/10.1177/1474474012462534

Blaser, M., H. A. Feit, and G. McRae, editors. 2004. In the way of development: indigenous peoples, life projects and globalization. Zed Books, London, UK.

Börjeson, L., M. Höjer, K.-H. Dreborg, T. Ekvall, and G. Finnveden. 2006. Scenario types and techniques: towards a user's guide. Futures 38(7):723-739. http://dx.doi.org/10.1016/j.

futures.2005.12.002

Bridge, G., and T. Perreault. 2009. Environmental governance. Pages 475-497 in N. Castree, D. Demeritt, D. Liverman, and B. Rhoads, editors. A companion to environmental geography. WileyBlackwell, Oxford, UK. http://dx.doi.org/10.1002/9781444305722. $\underline{\operatorname{ch} 28}$

Bryman, A. 2012. Social research methods. Fourth edition. Oxford University Press, Oxford, UK.

Bull, K. S., N. Oskal, and M. N. Sara. 2001. Reindriften $i$ Finnmark: rettshistorie 1852-1960. Cappelen akademisk, Oslo, Norway.

Cleaver, F. 2012. Development through bricolage: rethinking institutions for natural resource management. Routledge, London, UK.

Cornwall, A., and R. Jewkes. 1995. What is participatory research? Social Science and Medicine 41(12):1667-1676. https:// doi.org/10.1016/0277-9536(95)00127-S

Díaz, S., S. Demissew, J. Carabias, C. Joly, M. Lonsdale, N. Ash, A. Larigauderie, J. R. Adhikari, S. Arico, A. Báldi, A. Bartuska, I. A. Baste, A. Bilgin, E. Brondizio, K. M. A. Chan, V. E. Figueroa, A. Duraiappah, M. Fischer, R. Hill, T. Koetz, P. Leadley, P. Lyver, G. M. Mace, B. Martin-Lopez, M. Okumura, D. Pacheco, U. Pascual, E. S. Pérez, B. Reyers, E. Roth, O. Saito, R. J. Scholes, N. Sharma, H. Tallis, R. Thaman, R. Watson, T. Yahara, Z. A. Hamid, C. Akosim, Y. Al-Hafedh, R. Allahverdiyev, E. Amankwah, S. T. Asah, Z. Asfaw, G. Bartus, L. A. Brooks, J. Caillaux, G. Dalle, D. Darnaedi, A. Driver, G. Erpul, P. EscobarEyzaguirre, P. Failler, A. M. M. Fouda, B. Fu, H. Gundimeda, S. Hashimoto, F. Homer, S. Lavorel, G. Lichtenstein, W. A. Mala, W. Mandivenyi, P. Matczak, C. Mbizvo, M. Mehrdadi, J. P. Metzger, J. B. Mikissa, H. Moller, H. A. Mooney, P. Mumby, H. Nagendra, C. Nesshover, A. A. Oteng-Yeboah, G. Pataki, M. Roué, J. Rubis, M. Schultz, P. Smith, R. Sumaila, K. Takeuchi, S. Thomas, M. Verma, Y. Yeo-Chang, and D. Zlatanova. 2015. The IPBES conceptual framework - connecting nature and people. Current Opinion in Environmental Sustainability 14:1-16. http:// dx.doi.org/10.1016/j.cosust.2014.11.002

Dong, S., L. Wen, S. Liu, X. Zhang, J. P. Lassoie, S. Yi, X. Li, J. Li, and Y. Li. 2011. Vulnerability of worldwide pastoralism to global changes and interdisciplinary strategies for sustainable pastoralism. Ecology and Society 16(2):10. http://dx.doi. org/10.5751/ES-04093-160210

Eira, I. M. G. 2012. Muohttaga jávohis giella: Sámi árbevirolaš máhttu muohttaga birra dálkkádatrievdanáiggis. [The silent language of snow: Sámi traditional knowledge of snow in times of climate change]. Dissertation. University of Tromsø, Tromsø, Norway. [online] URL: http://hdl.handle.net/10037/9843
Eira, I. M. G., and M. N. Sara. 2017. Reindriftsnceringens erfaringsbaserte kunnskap om reindrift og rovvilt. Utredning på oppdrag fra Sametinget. Fylkesmannen, Vadsø, Norway. [online] URL: https://www.fylkesmannen.no/Documents/Dokument $\%$ 20FMNO/Landbruk $\% 20 \operatorname{og}^{\circ} \% 20$ mat $\% 20$ dokumenter/

Reindrift $\% 20$ dokumenter/Forskningsrapporter/Eira $\% 20 \mathrm{og} \% 20$ Sara $\%$ 202017 Reindriftsn $\% \mathrm{C} 3 \%$ A6ringens $\% 20$ erfarings

baserte $\% 20$ kunnskap $\% 20$ om $\% 20$ reindrift $\% 200 \mathrm{~g} \% 20$ rovvilt.pdf

Eira, I. M. G., M. N. Sara, H. Svarstad, and S. D. Mathiesen. 2016. A se som en stat eller som en samisk reineier: to forståelser av bærekraftig reindrift. Pages 27-48 in T. A. Benjaminsen, I. M. G. Eira, and M. N. Sara, editors. Samisk reindrift, norske myter. Fagbokforlaget, Bergen, Norway.

Escobar, A. 2010. Postconstructivist political ecologies. Pages 91-105 in M. R. Redclift and G. Woodgate, editors. The international handbook of environmental sociology. Second edition. Edward Elgar, Cheltenham, UK. http://dx.doi. org/10.4337/9781849805520.00015

Fauchald, P., T. Tveraa, N. G. Yoccoz, and R. A. Ims. 2004. En økologisk barekraftig reindrift: hva begrenser naturlig produksjon og høsting? Norsk institutt for naturforskning, Trondheim, Norway. [online] URL: http://www.nina.no/archive/nina/PppBasePdf/ fagrapport/076.pdf

Hætta, J. I., O. K. Sara, and I. Rushfeldt. 1994. Reindriften $i$ Finnmark: lovgivning og distriktsinndeling: forslag til ny distriktsinndeling i Finnmark. Reindriftsadministrasjonen, Alta, Norway.

Hay, C. 2006. Political ontology. Pages 78-96 in R. E. Goodin and C. Tilly, editors. The Oxford handbook of contextual political analysis. Oxford University Press, Oxford, UK. [online] URL: http://dx.doi.org/10.1093/oxfordhb/9780199270439.003.0004

Huntington, H. P., S. F. Trainor, D. C. Natcher, O. H. Huntington, L. DeWilde, and F. S. Chapin III. 2006. The significance of context in community-based research: understanding discussions about wildfire in Huslia, Alaska. Ecology and Society 11(1):40. http://dx.doi.org/10.5751/ES-01723-110140

Ims, A. A., and A. J. Kosmo. 2001. Høyeste reintall for distriktene $i$ Vest-Finnmark. Reindriftsforvaltningen, Alta, Norway.

International Centre for Reindeer Husbandry (ICR). 2006. Ethical guidelines for handling traditional knowledge at the International Centre for Reindeer Husbandry. International Centre for Reindeer Husbandry, Kautokeino, Norway. [online] URL: https://www.scribd.com/document/238393409/ICR-EthicalGuidelines

Jåma, E. M. 2017. Samisk reindrift, en saga blott? Trønder-Avisa 04 May 2017. [online] URL: http://www.t-a.no/meninger/2017/05/04/ Samisk-reindrift-en-saga-blott-14677590.ece

Johnsen, K. I. 2016. Medbestemmelse, makt og mistillit i reindriftsforvaltningen. Pages 195-220 in T. A. Benjaminsen, I. M. G. Eira, and M. N. Sara, editors. Samisk reindrift, norskemyter. Fagbokforlaget, Bergen, Norway.

Johnsen, K. I., and T. A. Benjaminsen. 2017. The art of governing and everyday resistance: "rationalization" of Sámi reindeer husbandry in Norway since the 1970s. Acta Borealia 34(1):1-25. http://dx.doi.org/10.1080/08003831.2017.1317981 
Johnsen, K. I., T. A. Benjaminsen, and I. M. G. Eira. 2015. Seeing like the state or like pastoralists? Conflicting narratives on the governance of Sámi reindeer husbandry in Finnmark, Norway. Norsk Geografisk Tidsskrift - Norwegian Journal of Geography 69 (4):230-241. http://dx.doi.org/10.1080/00291951.2015.1033747

Kontroll- og konstitusjonskomiteen. 2017. Innst. 493 S (2016-2017). Innstilling til Stortinget fra kontroll- og konstitusjonskomiteen. Stortinget, Oslo, Norway. [online] URL: https://www.stortinget.no/no/Saker-og-publikasjoner/Publikasjoner/ Innstillinger/Stortinget/2016-2017/inns-201617-493s/

Landbruks- og matdepartementet. 2008. Veileder for fastsetting av økologisk barekraftig reintall. Landbruks- og matdepartementet, Oslo, Norway. [online] URL: https://www.regjeringen.no/ globalassets/upload/lmd/vedlegg/

brosjyrer_veiledere_rapporter/veileder_fastsetting_okologisk_baerekraftig reintall des 2008.pdf

Landbruks- og matdepartementet. 2017. Meld. St. 32 (2016-2017) Reindrift: Lang tradisjon - unike muligheter. Landbruks- og matdepartementet, Oslo, Norway. [online] URL: https://www.regjeringen.no/no/dokumenter/meld.-st.-32-20162017/ id2547907/

Landbruks- og matdepartementet and Reindriftsforvaltningen. 2007. Orientering om Reindriftsloven av 15 juni 2007. Landbruksog matdepartementet, Oslo, Norway. [online] URL: http://www. regjeringen.no/Upload/LMD/Vedlegg/Brosjyrer veiledere rapporter/ Reindriftsloven_Norsk.pdf

Landbruksdepartementet. 1966. Innstilling fra Reindriftslovkomiteen. Landbruksdepartementet, Oslo, Norway. [online] URL: https:// www.stortinget.no/no/Saker-og-publikasjoner/Stortingsforhandlinger/ Lesevisning $/$ ?p=1976-77\&paid=4\&wid=a\&psid=DIVL480\&pgid= a $0707 \& v t=a \& d i d=$ DIVL $508 \& s=$ True

Landbruksdepartementet. 1976a. Ot. prp. 9 (1976-1977) Om lov om reindrift. Landbruksdepartementet, Oslo, Norway. [online] URL: https://www.stortinget.no/no/Saker-og-publikasjoner/ Stortingsforhandlinger $/$ Lesevisning/?p=1976-77\&paid=4\&wid=a\&psid= DIVL480

Landbruksdepartementet. 1976b. St. prp. 170 (1975-1976). Om hovedavtale for reindriftsnaringen. Landbruksdepartementet, Oslo, Norway. [online] URL: https://www.stortinget.no/no/ Saker-og-publikasjoner/Stortingsforhandlinger/Saksside/? pid=1970-1981\&mtid=85\&vt=b\&did=DIVL 70243

Landbruksdirektoratet. 2016. Ressursregnskap for reindriftsnœeringen: for reindriftsåret 1 April 2014-31 Mars 2015. Report 14/2016. Landbruksdirektoratet, Oslo, Norway. [online] URL: https:// www.landbruksdirektoratet.no/no/reindriften/for-siidaandeler/ publikasjoner/_attachment/51587?_ts $=15350981328 \&$ download= $\underline{\text { true }}$

Larsson, C.-G., D. R. Larsen, and N. J. Porsanger. 2017. Stortinget vil granske uretten mot samer og kvener: - Et dypt spørsmål for Norge. NRK Sámpi 20 June 2017. [online] URL: https://www.nrk.no/sapmi/stortinget-vil-granske-uretten-mot-samerog-kvener - -et-dypt-sporsmal-for-norge-1.13568636

Latour, B. 1993. We have never been modern. Harvard University Press, Cambridge, Massachusetts, USA.
Lenvik, D. 1988. Utvalgsstrategi $i$ reinflokken. Norges Landbrukshøgskole, Ås, Norway.

Lenvik, D. 1990. Flokkstrukturering: tiltak for lønnsom og ressurstilpasset reindrift. Rangifer Special Issue 4:21-35. [online] URL: http://septentrio.uit.no/index.php/rangifer/article/ download/908/869\&gathStatIcon=true

Lynam, T., W. de Jong, D. Sheil, T. Kusumanto, and K. Evans. 2007. A review of tools for incorporating community knowledge, preferences, and values into decision making in natural resources management. Ecology and Society 12(1):5. http://dx.doi. org/10.5751/ES-01987-120105

Magga, O. H., S. D. Mathiesen, R. W. Corell, and A. Oskal, editors. 2009. Reindeer herding, traditional knowledge and adaptation to climate change and loss of grazing land. Fagtrykk Idé, Alta, Norway. [online] URL: http://reindeerherding.org/wpcontent/uploads/2013/06/EALAT-Final-Report.pdf

Mistry, J., and A. Berardi. 2016. Bridging indigenous and scientific knowledge. Science 352(6291):1274-1275. http://dx.doi. org/10.1126/science.aaf1160

Mustonen, T., and K. Mustonen. 2011. Eastern Sámi atlas. Snowchange, Tampere, Finland.

Nadasdy, P. 1999. The politics of TEK: power and the "integration" of knowledge. Arctic Anthropology 36(1-2):1-18.

Nadasdy, P. 2005. The anti-politics of TEK: the institutionalization of co-management discourse and practice. Anthropologica 47(2):215-232.

Natcher, D. C. 2000. Constructing change: the evolution of land and resource management in Alberta, Canada. International Journal of Sustainable Development and World Ecology 7 (4):363-374. http://dx.doi.org/10.1080/13504500009470055

National Committee for Research Ethics in the Social Sciences and the Humanities (NESH). 2016. Guidelines for research ethics in the social sciences, humanities, law and theology. Fourth edition. Norwegian National Research Ethics Committees, Oslo, Norway. [online] URL: https://www.etikkom.no/globalassets/documents/ english-publications/60127 fek guidelines nesh digital corr.pdf

Niamir-Fuller, M. 2000. The resilience of pastoral herding in Sahelian Africa. Pages 250-284 in F. Berkes and C. Folke, editors. Linking social and ecological systems: management practices and social mechanisms for building resilience. Cambridge University Press, Cambridge, UK.

Nielsen, K. 1979. Lapp dictionary/Lappisk (Samisk) ordbok. Universitetsforlaget, Oslo, Norway.

Norgaard, R. B. 2006. Development betrayed: the end of progress and a coevolutionary revisioning of the future. Routledge, New York, New York, USA.

Norges offentlige utredninger (NOU). 2001. Forslag til endringer $i$ reindriftsloven: Innstilling fra Reindriftslovutvalget oppnevnt av Landbruksdepartementet 5 november 1998. Statens forvaltningstjeneste informasjonsforvaltning, Oslo, Norway. [online] URL: https:// www.regjeringen.no/contentassets/bbbc786f04474086baeac735f19cb6c4/ no/pdfa/nou200120010035000dddpdfa.pdf 
Oksala, J. 2010. Foucault's politicization of ontology. Continental Philosophy Review 43(4):445-466. http://dx.doi.org/10.1007/ $\underline{\text { s11007-010-9153-6 }}$

Oskal, N. 2000. On nature and reindeer luck. Rangifer 20 (2-3):175-180. http://dx.doi.org/10.7557/2.20.2-3.1511

Oteros-Rozas, E., B. Martín-López, T. M. Daw, E. L. Bohensky, J. R. A. Butler, R. Hill, J. Martin-Ortega, A. Quinlan, F. Ravera, I. Ruiz-Mallén, M. Thyresson, J. Mistry, I. Palomo, G. D. Peterson, T. Plieninger, K. A. Waylen, D. M. Beach, I. C. Bohnet, M. Hamann, J. Hanspach, K. Hubacek, S. Lavorel, and S. P. Vilardy. 2015. Participatory scenario planning in place-based social-ecological research: insights and experiences from 23 case studies. Ecology and Society 20(4):32. [online] URL: http://www. ecologyandsociety.org/vol20/iss4/art32/

Paine, R. 1994. Herds of the tundra: a portrait of Saami reindeer pastoralism. Smithsonian Institution Press, Washington, D.C., USA.

Paschen, J.-A., and R. Ison. 2014. Narrative research in climate change adaptation - exploring a complementary paradigm for research and governance. Research Policy 43(6):1083-1092. http:// dx.doi.org/10.1016/j.respol.2013.12.006

Pedersen, J., and T. A. Benjaminsen. 2008. One leg or two? Food security and pastoralism in the northern Sahel. Human Ecology 36(1):43-57. http://dx.doi.org/10.1007/s10745-007-9136-3

Peet, R., and E. Hartwick. 2009. Theories of development: contentions, arguments, alternatives. Second edition. Guilford Press, New York, New York, USA.

Ravna, Ø. 2015. Sami rights to natural resources and lands in Norway. Pages 63-77 in N. Loukacheva, editor. Polar law and resources. Nordic Council of Ministers, Copenhagen, Denmark.

Reindriftsforvaltningen. 2009. Veileder for utarbeidelse av bruksregler. Reindriftsforvaltningen, Alta, Norway.

Reindriftsstyret. 2011. Grunnlagsdokument for offentlig fastsettelse av ovre reintall for sommerbeitedistrikter $i$ VestFinnmark reinbeiteområde. Saksnr. 12/11. Møtedato: 14 april 2011. Reindriftsstyret, Tromsø, Norway.

Reindriftsstyret. 2012. Grunnlagsdokument - Reindriftsloven $\$ 60$ Vedtak om pålegg om forholdsmessig reduksjon. 63/12. Møtedato: 6 desember 2012. Reindriftsstyret, Oslo, Norway.

Reinert, E. S. 2006. The economics of reindeer herding: Saami entrepreneurship between cyclical sustainability and the powers of state and oligopolies. British Food Journal 108(7):522-540. http://dx.doi.org/10.1108/00070700610676352

Riseth, J. Å. 2000. Sámi reindeer management under technological change 1960-1990: implications for common-pool resource use under various natural and institutional conditions: A comparative analysis of regional development paths in West Finnmark, North Trøndelag, and South Trøndelag/Hedmark, Norway. Dissertation. Agricultural University of Norway, Ås, Norway. [online] URL: http://hdl.handle.net/10535/3618

Ruiz Serna, D., and C. Del Cairo. 2016. Los debates del giro ontológico en torno al naturalismo moderno [The ontological turn debates on modern naturalism]. Revista De Estudios Sociales 55:193-204. http://dx.doi.org/10.7440/res55.2016.13

Sagelvmo, A. 2004. Næringsavtaler og næringspolitikk (første gang trykt i år 2000 i Landbruksdepartementets jubileumsbok). Pages 56-72 in M. Stubsjøen, editor. Landbruksdirektøren fra Nord-Norge - Festskrift til Almar Sagelvmo. Landbruksdepartementet, Oslo, Norway. [online] URL: https://www.regjeringen.no/ globalassets/upload/kilde/ld/prm/2004/0025/ddd/pdfv/198909festskrift almar s.pdf

Sara, M. N. 2009. Siida and traditional Sámi reindeer herding knowledge. Northern Review 30(Spring 2009):153-178. [online] URL: http://journals.sfu.ca/nr/index.php/nr/article/view/9

Sara, M. N. 2013. Siida ja siiddastallan: A vare en siida - om forholdet mellom siidatradisjoner og videreforingen av siidasystemet [Being Siida - on the relationship between Siida tradition and continuation of the siida system]. Dissertation. Arctic University of Norway, Tromsø, Norway. [online] URL: http://hdl. handle.net/10037/8558

Simpson, L. R. 2004. Anticolonial strategies for the recovery and maintenance of indigenous knowledge. American Indian Quarterly 28(3-4):373-384. http://dx.doi.org/10.1353/aiq.2004.0107

Storli, I., and O. K. Sara. 1997. Reindrift før og nå. Landbruksforlaget, Oslo, Norway.

Tucker, V. 1999. The myth of development: a critique of a Eurocentric discourse. Pages 1-26 in R. Munck and D. O'Hearn, editors. Critical development theory: contributions to a new paradigm. Zed Books, London, UK.

Turi, E. I., and E. C. H. Keskitalo. 2014. Governing reindeer husbandry in western Finnmark: barriers for incorporating traditional knowledge in local-level policy implementation. Polar Geography 37(3):234-251. http://dx.doi.org/10.1080/1088937X.2$\underline{014.953620}$

Tveraa, T., P. Fauchald, N. G. Yoccoz, R. A. Ims, R. Aanes, and K. A. Høgda. 2007. What regulate and limit reindeer populations in Norway? Oikos 116(4):706-715. http://dx.doi.org/10.1111/ j.0030-1299.2007.15257.x

Vorren, Ø. 1946. Reindriften i Norge. Norsk Geografisk Tidsskrift - Norwegian Journal of Geography 11(5-6):199-220. http://dx.doi. org/10.1080/00291954608551627 